\title{
PENGARUH KONSELING MODIFIKASI GAYA HIDUP TERHADAP PENURUNAN ASUPAN NATRIUM, TEKANAN DARAH, DAN KADAR C-REACTIVE PROTEIN (CRP) PADA REMAJA OBESITAS DENGAN SINDROM METABOLIK
}

\author{
Addina Rizky F., M. Sulchan*) \\ Program Studi Ilmu Gizi Fakultas Kedokteran Universitas Diponegoro \\ J1.Dr.Sutomo No.18, Semarang, Telp (024) 8453708, Email : gizifk@ undip.ac.id
}

\begin{abstract}
Background: Metabolic syndrome is a predictor of cardiovascular disease. Lifestyle modification is one of the efforts to be made in the management of metabolic syndrome. This study aimed to analyze the effect of lifestyle modification counseling to decrease sodium intake, blood pressure, and levels of CRP in obese adolescent with metabolic syndrome.

Method: Non randomized pre-post test control group design involving 27 adolescent at SMA 2 Semarang. Lifestyle modification counseling was given to improve diet quality and physical activity for 2 months. Blood pressure was measured using a sphygmomanometer while the levels of CRP was measured using agglutination techniques. In the statistical analysis used independent-t test, Mann-Whitney, and Wilcoxon.

Result: Lifestyle modification counseling can improve diet quality and physical activity, also decrease sodium intake, systolic blood pressure, and levels of CRP. In the intensive counseling group, which includes levels of CRP, sodium intake, and diet quality has a significant difference $(p<0,05)$ between before and after the study. This study found that the diet quality in intensive counseling group better than their counterparts (1,09 versus 0,81). They consume less sodium intake (989 mg/day) than those who were unintensive counseling group (935 mg/day). Furthermore the decreased levels of CRP in intensive counseling group greater compared to their counterparts $(2,91 \mathrm{mg} / \mathrm{dL}$ versus $1,21 \mathrm{mg} / \mathrm{dL}$ ).

Conclusion: The effect of lifestyle modification counseling to improve the diet quality, increase physical activity, also decrease sodium intake, systolic blood pressure, and levels of CRP. Compare to unintensive counseling group, in the intensive counseling group improve diet quality, decrease sodium intake, and decrease levels of CRP but no increase in physical activity and decrease in blood pressure.
\end{abstract}

Keyword : counseling, lifestyle modification, obese adolescent, metabolic syndrome, CRP

\begin{abstract}
ABSTRAK
Latar Belakang: Sindrom metabolik merupakan prediktor dari penyakit kardiovaskular. Modifikasi gaya hidup merupakan salah satu upaya yang dapat dilakukan dalam penanganan sindrom metabolik. Penelitian ini bertujuan menganalisis pengaruh konseling modifikasi gaya hidup tehadap penurunan asupan natrium, tekanan darah, dan kadar CRP pada remaja obesitas dengan sindrom metabolik.

Metode: Desain penelitian ini adalah non randomized pre-post test control group design yang melibatkan 27 remaja di SMA 2 Semarang. Intervensi yang diberikan berupa konseling modifikasi gaya hidup untuk memperbaiki kualitas diet dan aktifitas fisik selama 2 bulan. Tekanan darah diukur menggunakan sphygmomanometer sedangkan kadar CRP diukur menggunakan teknik aglutinasi. Pada analisis statistik digunakan uji independent-t-test, Mann Whitney, dan Wilcoxon.

Hasil: Konseling modifikasi gaya hidup dapat meningkatkan kualitas diet dan aktivitas fisik serta menurunkan asupan natrium, tekanan darah sistolik, dan kadar CRP. Pada kelompok konseling intensif, variabel yang meliputi kualitas diet, asupan natrium, dan kadar CRP memiliki perbedaan yang signifikan ( $<<0,05)$ antara sebelum dan sesudah penelitian. Pada kelompok konseling intensif, kualitas diet (1,09) lebih baik daripada kelompok konseling tidak intensif (0,81), penurunan asupan natrium (989) lebih baik daripada kelompok konseling tidak intensif (935), sedangkan penurunan kadar CRP (2,91) lebih tinggi dibandingkan dengan konseling tidak intensif $(1,21)$.

Simpulan: Konseling modifikasi gaya hidup berpengaruh terhadap peningkatan kualitas diet dan aktifitas fisik serta penurunan asupan natrium, tekanan darah sistolik, dan kadar CRP. Dibandingkan dengan kelompok konseling tidak intensif, pada kelompok konseling intensif terjadi peningkatan kualitas diet, penurunan asupan natrium dan kadar CRP tetapi tidak terjadi peningkatan aktifitas fisik dan penurunan tekanan darah.
\end{abstract}

Kata kunci: konseling, modifikasi gaya hidup, remaja obesitas, sindrom metabolik, CRP

\section{PENDAHULUAN}

Obesitas merupakan masalah yang terjadi di seluruh dunia dan prevalensinya mengalami peningkatan baik di negara maju maupun negara berkembang. ${ }^{1,2}$ Peningkatan prevalensi obesitas pada remaja berkontribusi terhadap penyakit kronis, salah satu diantaranya adalah sindrom metabolik. ${ }^{3,4}$ Sindrom metabolik merupakan kumpulan gangguan

\footnotetext{
${ }^{*}$ Penulis Penanggungjawab
} 
dan kelainan metabolisme yang mencakup obesitas, peningkatan trigliserida dan penurunan High Density Lipoprotein (HDL), gangguan glukosa, serta hipertensi. ${ }^{3-6}$ Menurut National Cholesterol Education Program Adult Treatment Panel (NCEP-ATP) III, seseorang dikatakan sindrom metabolik apabila memenuhi kriteria sebanyak tiga atau lebih. ${ }^{1,7}$ Sindrom metabolik merupakan prediktor dari penyakit kardiovaskular. Faktor genetik, lingkungan sosial, dan faktor perilaku seperti pola makan yang kurang sehat dan gaya hidup sedenter berhubungan erat dengan peningkatan prevalensi obesitas dan sindrom metabolik pada remaja. ${ }^{3}$

Gaya hidup masa kini mengubah peran makanan, tidak hanya sebagai kebutuhan primer dalam pemenuhan zat gizi yang dibutuhkan oleh tubuh tetapi juga sebagai gaya hidup. Hal ini menyebabkan perkembangan pesat pada pembangunan restoran cepat saji di perkotaan. Restoran cepat saji biasanya menyajikan makanan tinggi karbohidrat, tinggi lemak, tinggi natrium dan rendah serat. ${ }^{8}$ Asupan natrium yang melebihi batas normal berkaitan dengan tekanan darah. Hal ini berkaitan dengan kemampuan ginjal yang meretensi cairan sehingga terjadi peningkatan volume darah serta berpengaruh terhadap penyempitan pembuluh darah. ${ }^{9,10}$ Hipertensi merupakan salah satu kriteria dalam diagnosis sindrom metabolik. ${ }^{3-6}$ Mekanisme yang memungkinkan terjadinya hipertensi terkait dengan sindrom metabolik adalah dampak dari disfungsi jaringan adiposa yang menyebabkan sekresi adipositokin berupa angiotensinogen dan angiotensin II yang dapat meningkatkan tekanan darah. ${ }^{11}$

Perkembangan sindrom metabolik yang terjadi pada usia remaja akan berlanjut hingga usia dewasa. ${ }^{2,3,5}$ Penelitian yang dilakukan di SMP Domenico Savio Kota Semarang tahun 2009 menunjukkan bahwa prevalensi sindrom metabolik pada remaja obesitas sebesar $31,6 \% .^{1}$ Penelitian yang dilakukan di SMP dan SMA Kota Malang tahun 2011 menunjukkan prevalensi sindrom metabolik sebesar 48,6\%. ${ }^{6}$ Berdasarkan penelitian di SMA 2 Semarang tahun 2014 menunjukkan $15,2 \%$ remaja obesitas mengalami sindrom metabolik. ${ }^{13}$

Pada seseorang yang mengalami obesitas dengan sindrom metabolik terjadi peningkatan lemak viseral pada abdominal. Faktor yang berkontribusi dalam proses ini adalah ketidakseimbangan antara asupan energi dan pengeluaran energi yang menyebabkan perubahan metabolisme dalam jaringan adiposa serta sistem organ lain termasuk pankreas, hipotalamus, otot, dan hati. ${ }^{14}$ Sindrom metabolik berkaitan dengan disregulasi jaringan adiposa sehingga meningkatkan sekresi adipositokin proinflamasi. ${ }^{2,6}$ Beberapa penelitian telah mengidentifikasi tanda klinis yang mampu memprediksi perkembangan sindrom metabolik, salah satunya adalah $C$ Reactive Protein (CRP). CRP adalah salah satu protein fase akut yang disintesis oleh hepatosit dan terdapat pada serum normal dalam konsentrasi yang sangat sedikit. ${ }^{4,15}$ Peningkatan kadar CRP digunakan sebagai tanda sensitif dari inflamasi sistemik yang mengindikasikan bahwa telah terjadi penyakit kronis dalam tubuh. ${ }^{14,16}$

Asupan natrium yang berlebihan berkaitan dengan kualitas diet yang rendah berdampak terhadap peningkatan jaringan adiposa, resistensi leptin, sekresi sitokin proinflamasi, dan peningkatan tekanan darah. ${ }^{17,18}$ Dalam menangani masalah sindrom metabolik diperlukan sebuah intervensi yang dapat menurunkan asupan natrium, tekanan darah, dan kadar CRP. Salah satu intervensi yang dapat dilakukan adalah konseling modifikasi gaya hidup terkait dengan perubahan kualitas diet dan peningkatan aktivitas fisik. ${ }^{9,15,19}$ Modifikasi gaya hidup melalui pembatasan energi dan berjalan kaki $30 \mathrm{menit} / \mathrm{hari}$ selama lima hari dalam seminggu dapat mengurangi berat badan sebesar 5\% sehingga dapat menurunkan CRP dan tekanan darah. ${ }^{20}$ Selain itu, pembatasan asupan energi dan peningkatan aktifitas fisik selama 12 minggu dapat meningkatkan sekresi sitokin antiinflamasi (adiponektin dan IL-10) dan menurunkan sekresi sitokin proinflamasi (TNF- $\alpha$ dan IL-6) meskipun belum terjadi penurunan berat badan. ${ }^{11}$

\section{METODE}

Penelitian dilakukan di SMA 2 Semarang pada bulan September-November 2014. Penelitian ini termasuk dalam ruang lingkup gizi masyarakat dengan rancangan non randomized pre-post test control group design. Variabel bebas (independent) adalah konseling dan pendampingan dalam membantu modifikasi gaya hidup terkait dengan kualitas diet dan aktifitas fisik. Variabel terikat (dependent) dalam penelitan ini adalah asupan natrium, tekanan darah, dan kadar CRP.

Populasi dalam penelitian ini adalah remaja siswa-siswi kelas XI dan XII yang memenuhi kriteria inklusi dan eksklusi. Kriteria inklusi yang digunakan adalah remaja usia 15-18 tahun yang mengalami obesitas ditandai dengan IMT $\geq$ persentil ke-95 grafik persentil IMT, dan obesitas sentral (lingkar pinggang $\geq$ persentil ke-90, yaitu $\geq 93 \mathrm{~cm}$ untuk laki-laki dan $\geq 87 \mathrm{~cm}$ untuk perempuan). Kriteria eksklusi adalah subyek yang 
mengundurkan diri dan meninggal dunia saat penelitian berlangsung. Dari populasi yang memenuhi kriteria inklusi sebesar 38 siswa dan siswi digunakan sebagai subyek penelitian. Namun seiring berjalannya proses penelitian, satu per satu subyek mulai mengundurkan diri sehingga data lengkap hanya diperoleh 27 subyek pada akhir penelitian.

Intervensi yang diberikan berupa konseling yang dilanjutkan dengan pendampingan sebanyak 8 kali. Seluruh subyek penelitian diberikan konseling dan ditawarkan untuk mengikuti pendampingan yang dilakukan berdasarkan kesanggupan subyek. Oleh karena itu intensitas konseling modifikasi gaya hidup ditentukan oleh keikutsertaan dalam pendampingan, dikategorikan menjadi konseling intensif (1-8 kali) dan konseling tidak intensif (0). Konseling mengenai mekanisme sindrom metabolik dan modifikasi gaya hidup pada sindrom metabolik diberikan pada subyek dan orang tuanya di awal penelitian. Pendampingan dilakukan seminggu sekali dengan memberikan pengetahuan mengenai cara memaknai hasil laboratorium, obesitas dan hubungannya dengan sindrom metabolik, pengelolaan berat badan, pola makan seimbang, cara membaca label makanan, pemilihan makanan di luar rumah, gaya hidup sedenter dan peningkatan aktivitas fisik. ${ }^{21}$ Materi tersebut selain disampaikan melalui pendampingan juga diberikan melalui booklet yang diberikan ke subyek penelitian.

Data yang dikumpulkan berupa identitas subyek, meliputi nama, usia/tanggal lahir, jenis kelamin, pendidikan, dan alamat tempat tinggal diperoleh melalui wawancara yang dicatat pada kuesioner data umum subyek. Data antropometri, meliputi berat badan, tinggi badan, dan lingkar pinggang. Pengukuran berat badan menggunakan timbangan berat badan dengan ketelitian $0,1 \mathrm{~kg}$ sedangkan pengukuran tinggi badan menggunakan microtoise dengan ketelitian $0,1 \mathrm{~cm}$ dan pengukuran lingkar pinggang menggunakan pita ukur/metlin dengan ukuran maksimal $150 \mathrm{~cm}$. Pengukuran tekanan darah dilakukan oleh perawat menggunakan sphygmomanometer air raksa menggunakan metode tidak langsung dengan cara auskultasi sebanyak 2 kali. Batasan tekanan darah pada remaja menggunakan persentil $\geq 90$ dengan angka >122/77 mmHg. Pengukuran CRP menggunakan metode aglutinasi latex dengan batasan nilai $>6 \mathrm{mg} / \mathrm{dL}$.

Data mengenai gaya hidup diperoleh melalui wawancara, yang berkaitan dengan kualitas diet menggunakan modifikasi Diet Quality Index
(DQI) sedangkan aktivitas fisik menggunakan International Physical Activity Questionnary (IPAQ). Data asupan makanan diperoleh melalui wawancara menggunakan Semiquantitative Food Frequency Questionnary (FFQ). Kualitas diet digunakan untuk menilai konsumsi makanan yang terdiri dari asupan lemak, kolesterol, natrium, serat, dan densitas energi berdasarkan kesesuaian terhadap rekomendasi diet. Apabila konsumsi zat gizi tersebut sesuai dengan rekomendasi diet maka diberi skor 2 sedangkan konsumsi zat gizi yang tidak sesuai dengan rekomendasi diet maka diberi skor 1. Perhitungan akumulasi skor DQI terdiri dari dua kategori, yaitu kualitas diet rendah apabila kurang dari nilai median dan kualitas diet yang baik apabila lebih dari nilai median. Penilaian aktifitas fisik terdiri dari tiga kategori, 1) rendah, apabila $<600$ MET-menit/minggu, 2) sedang, apabila 6002999 MET-menit/minggu, 3) tinggi, apabila $\geq 3000$ MET-menit/minggu. ${ }^{23}$

Analisis data dilakukan dengan menggunakan program komputer. Analisis deskriptif untuk mendeskripsikan rerata, standar deviasi, nilai minimal dan maksimal semua variabel pada semua subyek penelitian secara keseluruhan, kelompok intensif dan tidak intensif. Analisis bivariat digunakan untuk menguji perbedaan kualitas diet, asupan natrium, aktifitas fisik, tekanan darah sistolik, tekanan darah diastolik, dan kadar CRP antara kelompok konseling intensif dan tidak intensif, baik sebelum maupun sesudah intervensi. Untuk menguji perbedaan antara kelompok konseling intensif dan tidak intensif digunakan uji independen $T$ Test dan Man Whitney. Untuk menguji perbedaan antara sebelum dan sesudah intervensi digunakan Wilcoxon pada masingmasing kelompok.

\section{HASIL PENELITIAN}

Hasil dari penelitian awal ditemukan prevalensi sindrom metabolik di SMA 2 Semarang sebesar $15,2 \%$. Pemeriksaan komponen sindrom metabolik pada tekanan darah menunjukkan bahwa nilai median tekanan sistolik sebesar 130 (120-140) $\mathrm{mmHg}$ dan nilai median tekanan diastolik sebesar 70 (70-80) mmHg. Gambaran kadar CRP tinggi berdasarkan jenis kelamin menunjukkan bahwa perempuan $(53,8 \%)$ memiliki frekuensi lebih besar dibandingkan dengan laki-laki (46,2\%). Asupan natrium harian menunjukkan bahwa sebesar $84,1 \%$ subyek penelitian yang asupannya > 2300 $\mathrm{mg} / \mathrm{hari}^{13}$ 
Tabel 1. Nilai Rerata dan Standar Deviasi Kualitas Diet, Aktivitas Fisik, Asupan Natrium, Tekanan Darah, dan Kadar CRP Subyek Sebelum dan Sesudah Penelitian

\begin{tabular}{lccc}
\hline \multicolumn{1}{c}{ Variabel } & Pre & Post & Sig $(\boldsymbol{p})$ \\
\hline Kualitas Diet & $6,33 \pm 1,07$ & $7,26 \pm 0,76$ & 0,00 \\
Aktivitas Fisik (MET/menit/minggu) & $1401,27 \pm 1333,74$ & $2119,98 \pm 1768,07$ & 0,00 \\
Asupan Natrium (mg/hari) & $2841,22 \pm 935,71$ & $1883,76 \pm 670,54$ & 0,00 \\
Asupan Natrium >2300 mg/hari & $23(85,2 \%)$ & $7(25,9 \%)$ & \\
Tekanan Sistolik (mmHg) & $120,56 \pm 10,31$ & $116,30 \pm 6,87$ & 0,04 \\
Tekanan Diastolik (mmHg) & $71,67 \pm 3,66$ & $73,70 \pm 5,64$ & $0,06^{*}$ \\
CRP (mg/dL) & $6,97 \pm 3,92$ & $5,07 \pm 0,26$ & 0,01 \\
CRP $>$ 6 mg/dL & $8(29,6 \%)$ & $2(7,4 \%)$ & \\
\hline
\end{tabular}

* Tidak Signifikan

Tabel 1 menunjukkan rerata dan standar deviasi dari kualitas diet, aktivitas fisik, asupan natrium, tekanan darah dan kadar CRP sebelum dan sesudah penelitian. Secara keseluruhan, sebagian besar variabel yang meliputi kualitas diet, aktivitas fisik, asupan natrium, dan kadar CRP menunjukkan perbedaan yang signifikan $(p<0,05)$ antara sebelum dan sesudah penelitian. Lain halnya dengan tekanan darah sistolik dan tekanan darah diastolik yang tidak menunjukkan perbedaan yang signifikan $(p>0,05)$ antara sebelum dan sesudah penelitian.

Tabel 2. Proporsi Frekuensi Konseling

\begin{tabular}{ccc}
\hline Kategori Konseling & Jumlah Pertemuan & Presentase \\
\hline Intensif & $5-8$ & $3(11,11 \%)$ \\
& $1-4$ & $8(29,62 \%)$ \\
Tidak Intensif & 0 & $16(59,25 \%)$ \\
\hline & Jumlah & $27(100 \%)$ \\
\hline
\end{tabular}

Tabel 2 menunjukkan bahwa jumlah subyek dalam penelitian ini adalah 27 remaja obesitas. Seluruh subyek penelitian mengikuti konseling pada awal penelitian. Selanjutnya hanya
11 orang yang bersedia mengikuti konseling intensif dengan variasi pendampingan 1-8 kali dan 16 siswa-siswi yang tergolong dalam konseling tidak intensif.

Tabel 3. Rerata Umur dan Proporsi Jenis Kelamin Menurut Intensitas Konseling

\begin{tabular}{|c|c|c|c|c|c|}
\hline \multirow[t]{3}{*}{ Konseling } & \multirow[t]{3}{*}{$\mathbf{n}$} & \multicolumn{3}{|c|}{ Variabel } & \multirow[t]{3}{*}{ Total } \\
\hline & & \multirow[t]{2}{*}{ Umur } & \multicolumn{2}{|c|}{ Jenis Kelamin } & \\
\hline & & & Laki-Laki & Perempuan & \\
\hline Intensif & 11 & $16(16-18)$ & $5(45,5 \%)$ & $6(54,5 \%)$ & $11(100 \%)$ \\
\hline Tidak intensif & 16 & $17(16-18)$ & $14(87,5 \%)$ & $2(12,5 \%)$ & $16(100 \%)$ \\
\hline Total & 27 & $16(16-18)$ & $19(70,37 \%)$ & $8(29,63 \%)$ & $27(100 \%)$ \\
\hline
\end{tabular}

Tabel 3 menunjukkan bahwa subyek penelitian yang mengikuti konseling intensif sebagian besar remaja putri $(54,5 \%)$, sedangkan yang tergolong dalam konseling tidak intensif sebagian besar remaja putra $(87,5 \%)$. Umur subyek pada siswa-siswi yang intensif sedikit lebih muda dibandingkan dengan siswa-siswi yang tidak intensif dalam melakukan pendampingan.

Tabel 4. Perbedaan Kualitas Diet, Aktivitas Fisik, Asupan Natrium, Tekanan Darah, dan Kadar CRP Antara Kelompok Konseling Intensif dan Tidak Intensif Sebelum Penelitian

\begin{tabular}{lccc}
\hline \multirow{2}{*}{ Variabel } & \multicolumn{2}{c}{ Rerata \pm SD } & Sig $(\boldsymbol{p})$ \\
\cline { 2 - 3 } & Tidak Intensif & Intensif & \\
\hline Kualitas Diet & $6,5 \pm 1,15$ & $6,09 \pm 0,944$ & 0,34 \\
Aktivitas Fisik & $1246,33 \pm 1234,95$ & $1626,63 \pm 1497,69$ & 0,49 \\
(MET/menit/minggu) & & & \\
Asupan Na (mg/hari) & $2901,21 \pm 1071,76$ & $2753,95 \pm 734,37$ & 0,69 \\
TS (mmHg) & $121,25 \pm 10,72$ & $119,55 \pm 10,11$ & 0,68 \\
TD (mmHg) & $72,19 \pm 4,07$ & $70,91 \pm 3,01$ & 0,32 \\
CRP (mg/dL) & $6,27 \pm 3,52$ & $8,005 \pm 4,39$ & $0,03^{*}$ \\
\hline
\end{tabular}


Tabel 4 menyajikan secara statistik bahwa variabel kualitas diet, aktivitas fisik, asupan natrium, tekanan darah sistolik, dan tekanan darah diastolik menunjukkan tidak ada perbedaan yang signifikan $(p>0,05)$ antara kelompok konseling intensif dan tidak intensif. Namun pada kadar CRP menunjukkan perbedaan yang signifikan $(p<0,05)$ antara kelompok konseling intensif dan tidak intensif sebelum penelitian.

Tabel 5. Perbedaan Kualitas Diet, Aktivitas Fisik, Asupan Natrium, Tekanan Darah, dan Kadar CRP Antara Kelompok Konseling Intensif dan Tidak Intensif Sebelum dan Sesudah Penelitian

\begin{tabular}{|c|c|c|c|c|c|c|}
\hline \multirow[t]{2}{*}{ Variabel } & \multicolumn{2}{|c|}{$\begin{array}{c}\text { Tidak Intensif } \\
\text { Rerata } \pm \text { SD }\end{array}$} & \multirow[t]{2}{*}{$\begin{array}{l}\text { Sig } \\
(p)\end{array}$} & \multicolumn{2}{|c|}{$\begin{array}{c}\text { Intensif } \\
\text { Rerata } \pm \text { SD } \\
\end{array}$} & \multirow[t]{2}{*}{$\begin{array}{l}\text { Sig } \\
(p)\end{array}$} \\
\hline & Pre & Post & & Pre & Post & \\
\hline Kualitas Diet & $6,5 \pm 1,15$ & $7,31 \pm 0,704$ & $0,04 *$ & $6,09 \pm 0,944$ & $7,18 \pm 0,874$ & $0,01 *$ \\
\hline $\begin{array}{l}\text { Aktivitas Fisik } \\
\text { (MET- } \\
\text { menit/minggu) }\end{array}$ & $1246,33 \pm 1234,95$ & $2335,81 \pm 2044,57$ & $0,00 *$ & $1626,63 \pm 1497,69$ & $1806,04 \pm 1294$ & 0,18 \\
\hline $\begin{array}{l}\text { Asupan } \mathrm{Na} \\
(\mathrm{mg} / \mathrm{hari})\end{array}$ & $2901,21 \pm 1071,76$ & $1965,57 \pm 801,47$ & $0,00^{*}$ & $2753,95 \pm 734,37$ & $1764,76 \pm 423,3$ & $0,00 *$ \\
\hline $\mathrm{TS}(\mathrm{mmHg})$ & $121,25 \pm 10,72$ & $116,88 \pm 7,04$ & 0,08 & $119,55 \pm 10,11$ & $115,45 \pm 6,87$ & 0,24 \\
\hline TD (mmHg) & $72,19 \pm 4,07$ & $73,75 \pm 5$ & 0,22 & $70,91 \pm 3,01$ & $73,64 \pm 6,74$ & 0,18 \\
\hline CRP (mg/dL) & $6,27 \pm 3,52$ & $5,06 \pm 0,25$ & 0,18 & $8,005 \pm 4,39$ & $5,09 \pm 0,301$ & $0,02 *$ \\
\hline
\end{tabular}

* Signifikan

Tabel 5 menunjukkan bahwa kelompok konseling intensif, variabel yang meliputi kualitas diet, asupan natrium, dan kadar CRP memiliki perbedaan yang signifikan $(p<0,05)$ antara sebelum dan sesudah penelitian. Namun, pada aktivitas fisik, tekanan darah sistolik, dan tekanan darah diastolik tidak ada perbedaan yang signifikan $(p>0,05)$. Pada kelompok konseling tidak intensif, variabel yang meliputi, tekanan darah sistolik, tekanan darah diastolik, dan kadar CRP menunjukkan tidak ada perbedaan yang signifikan $(p>0,05)$. Namun, untuk kualitas diet, aktivitas fisik, dan asupan natrium terdapat perbedaan yang signifikan $(p<0,05)$ antara sebelum dan sesudah penelitian.

Tabel 6. Perbandingan Perubahan Rerata Kualitas Diet, Aktivitas Fisik, Asupan Natrium, Tekanan Darah, dan Kadar CRP Sebelum dan Sesudah Penelitian Pada Kelompok Konseling yang Intensif dan Tidak Intensif

\begin{tabular}{lccc}
\hline \multicolumn{1}{c}{ Variabel } & \multicolumn{2}{c}{ Rerata \pm SD } & Sig $(\boldsymbol{p})$ \\
\cline { 2 - 3 } & Tidak Intensif & Intensif & \\
\hline$\Delta$ Kualitas Diet & $0,81 \pm 1,47$ & $1,09 \pm 1,04$ & 0,59 \\
$\Delta$ Aktivitas Fisik & $1089,47 \pm 1373,68$ & $179,40 \pm 524,15$ & 0,13 \\
(MET-menit/minggu) & & & \\
$\Delta$ Asupan Natrium (mg/hari) & $-935,64 \pm 1000,27$ & $-989,18 \pm 539,06$ & 0,27 \\
$\Delta$ Tekanan Sistolik (mmHg) & $-4,37 \pm 10,14$ & $-4,09 \pm 11,13$ & 0,89 \\
$\Delta$ Tekanan Diastolik (mmHg) & $1,56 \pm 5,69$ & $2,72 \pm 6,46$ & 0,55 \\
$\Delta$ CRP $(\mathrm{mg} / \mathrm{dL})$ & $-1,21 \pm 3,33$ & $-2,91 \pm 4,24$ & $0,03^{*}$ \\
\hline
\end{tabular}

* Signifikan

Tabel 6 menunjukkan bahwa perubahan rerata kadar CRP antara sebelum dan sesudah penelitian mempunyai perbedaan yang signifikan $(p<0,05)$ antara kelompok konseling intensif dan tidak intensif. Penurunan kadar CRP lebih besar terdapat pada kelompok konseling intensif $(2,91 \pm 4,24)$ dibandingkan dengan kelompok konseling tidak intensif $(1,21 \pm 3,33)$. Namun, perubahan rerata kualitas diet, aktivitas fisik, asupan natrium, dan tekanan darah antara sebelum dan sesudah penelitian tidak ada perbedaan yang signifikan $(p>0,05)$ antara kelompok konseling intensif dan tidak intensif.

\section{PEMBAHASAN}

Usia subyek penelitian relatif homogen yaitu berkisar antara 16-18 tahun yang termasuk dalam kategori remaja akhir. Proporsi jenis kelamin subyek penelitian lebih banyak pada remaja putra $(70,37 \%)$ dibandingkan dengan remaja putri $(29,63 \%)$. Tingginya prevalensi remaja putra pada kejadian sindrom metabolik sejalan dengan penelitian yang dilakukan di Semarang pada tahun 2009 dengan prevalensi sindrom metabolik pada remaja putra sebesar $25,6 \%$ sedangkan pada remaja putri sebesar $11,8 \%$. Laki-laki dengan obesitas cenderung mempunyai akumulasi lemak di bagian abdomen yang disebut dengan obesitas sentral. 
Obesitas sentral menempati urutan pertama yang berkontribusi terhadap kejadian sindrom metabolik. ${ }^{13}$ Jika terdapat lemak viseral yang berlebihan maka dapat meningkatkan lipolisis sehingga memicu peningkatan asam lemak bebas dan terjadinya resistensi insulin. ${ }^{12}$

Konseling merupakan salah satu metode yang dapat digunakan dalam upaya peningkatan pengetahuan dan kesadaran sehingga dapat merubah perilaku dan gaya hidup. Teori perilaku yang dikemukakan oleh H.L Blum menunjukkan bahwa perubahan perilaku dapat terjadi setelah adanya perubahan pada pengetahuan dan sikap. Interaksi dari berbagai komponen perilaku yang kompleks menyebabkan proses perubahan perilaku membutuhkan waktu yang lama. ${ }^{24}$ Apabila proses perubahan perilaku dan gaya hidup didasari oleh pengetahuan, kesadaran, serta sikap positif maka perilaku tersebut akan bersifat jangka panjang. Dalam penelitian ini konseling tidak hanya diberikan kepada remaja yang mengalami sindrom metabolik tetapi juga kepada orang tuanya. Namun karena kesibukan dan berhalangan hadir menyebabkan hanya beberapa orang tua $(21,05 \%)$ yang dapat hadir dalam mengikuti konseling pada awal penelitian.

Kelompok konseling intensif sebagian besar adalah remaja putri. Hal ini dapat terjadi karena ketidakpuasan remaja putri terhadap citra tubuh yang dapat berdampak pada masalah psikososial, diantaranya adalah stress dan kurang percaya diri. ${ }^{25}$ Oleh karena itu konseling intensif yang membantu modifikasi gaya hidup dapat meningkatkan motivasi dalam upaya pencapaian bentuk tubuh yang lebih ideal. ${ }^{26}$ Pada kelompok konseling yang tidak intensif sebagian besar adalah remaja putra. Remaja putra dengan obesitas cenderung memiliki rasa percaya diri yang lebih tinggi jika dibandingkan dengan remaja putri. ${ }^{27} \mathrm{Hal}$ ini dikarenakan remaja putra tidak menekankan rasa percaya diri terhadap citra tubuh dan penampilan fisik. $^{25}$

Dalam menunjang modifikasi gaya hidup diperlukan motivasi dan komitmen yang tinggi untuk dapat melakukan perubahan perilaku. Sebelum penelitian, kualitas diet pada seluruh subyek penelitian relatif homogen dengan nilai rerata 6. Dengan mengikuti konseling terjadi perubahan perilaku hidup sehat pada subyek. Perilaku hidup sehat dengan meningkatkan kualitas diet pada subyek meningkat jika dilihat dari nilai rerata dan signifikan $(p<0,05)$. Peningkatan kualitas diet lebih besar terjadi pada subyek yang mengikuti konseling intensif $(1,09 \pm 1,47)$ dibandingkan dengan subyek yang mengikuti konseling tidak intensif $(0,81 \pm 1,04)$. Peningkatan kualitas diet lebih besar terjadi pada remaja putri dari nilai rerata 6,13 menjadi 7,75 , sedangkan pada remaja putra mengalami peningkatan kualitas diet dari nilai rerata 6,42 menjadi 7,05. Jika kualitas diet seseorang semakin baik maka konsumsi makanan yang sesuai dengan rekomendasi diet menjadi semakin baik. ${ }^{28}$ Secara keseluruhan, wanita memiliki kebiasaan diet yang lebih sehat dibandingkan dengan pria. Hal ini berkaitan dengan perbedaan gender terhadap faktor biologis, psikososial, dan tanggung jawab sehingga berpengaruh terhadap perilaku hidup sehat dan penurunan berat badan. ${ }^{29}$

Sebelum penelitian, aktivitas fisik seluruh subyek termasuk dalam kategori sedang yaitu berkisar 600-2999 MET-menit/minggu. ${ }^{23}$ Rerata aktivitas fisik sebelum penelitian adalah 1401,27 MET-menit/minggu. Sesudah penelitian, aktivitas fisik mengalami peningkatan nilai rerata dan signifikan $(p<0,05)$. Peningkatan aktivitas fisik lebih besar terjadi pada remaja putra dibandingkan dengan remaja putri. Sebelum penelitian, remaja putra memiliki nilai rerata 1445,33 METmenit/minggu dan setelah penelitian nilai rerata aktivitas fisik 2334,07 MET-menit/minggu. Aktivitas fisik yang memadai berpengaruh terhadap penurunan persentase lemak tubuh sehingga dapat mengurangi obesitas dan penyakit kardiovaskular. ${ }^{12}$ Aktifitas fisik yang dianjurkan oleh WHO untuk remaja adalah meliputi aktifitas fisik sedang dan berat yang terakumulasi selama 60 menit/hari. ${ }^{22}$

Asupan natrium merupakan salah satu faktor yang dapat meningkatkan tekanan darah. Rerata asupan natrium pada subyek sebelum penelitian lebih tinggi jika dibandingkan dengan anjuran untuk remaja usia 14-18 yaitu >2300 $\mathrm{mg} /$ hari. ${ }^{13}$ Saat asupan natrium berlebihan dan tubuh tidak dapat mengekskresikannya maka terjadi peningkatan kadar natrium dalam darah. Hal ini berkaitan dengan kemampuan ginjal yang meretensi cairan sehingga terjadi peningkatan volume darah dan curah jantung yang menyebabkan tekanan darah meningkat. ${ }^{13,17}$ Asupan natrium harian subyek penelitian memiliki perbedaan yang signifikan antara sebelum dan sesudah intervensi $(p<0,05)$. Pemberian konseling intensif berkaitan dengan modifikasi gaya hidup berhasil menurunkan asupan natrium harian subyek penelitian dari rerata 2753,95 $\mathrm{mg} /$ hari menjadi $1764,76 \mathrm{mg} /$ hari.

Pengaruh konseling modifikasi gaya hidup terkait dengan kualitas diet dan aktivitas fisik terhadap penurunan tekanan darah antara kelompok konseling intensif dan tidak intensif tidak memiliki perbedaan yang signifikan sesudah penelitian 
$(p>0,05)$. Sebelum penelitian, rerata tekanan darah pada subyek penelitian berada pada rentang nilai normal yaitu $<122 / 77 \mathrm{mmHg}$. Pengukuran tekanan darah pada subyek penelitian hanya dilakukan pada sebelum dan sesudah penelitian. Diagnosis hipertensi pada remaja dapat ditegakkan apabila dilakukan pengukuran ulang dan evaluasi lanjutan. Pengukuran ulang pada peningkatan tekanan darah diperlukan karena tekanan darah bersifat tidak statis dan bervariasi serta tekanan darah yang tinggi dapat mengalami penurunan pada pengukuran berikutnya akibat berkurangnya kecemasan dari kunjungan pertama ke kunjungan berikutnya. Pengukuran tekanan darah yang tepat dipengaruhi oleh kondisi subyek saat diperiksa, kualitas peralatan, dan keterampilan pemeriksa. ${ }^{30}$

Rerata kadar CRP pada subyek penelitian ditemukan tinggi pada sebelum penelitian baik pada kelompok konseling intensif maupun tidak intensif. Pada remaja obesitas, hipertropi pada sel adiposit menyebabkan terjadinya hipoksia yang menstimulasi sekresi sitokin proinflamasi. ${ }^{17}$ Hasil penelitian ini menunjukkan bahwa konseling modifikasi gaya hidup berkaitan dengan kualitas diet dan aktivitas fisik selama 2 bulan dapat menurunkan kadar CRP secara signifikan. Penurunan kadar CRP lebih besar terjadi pada kelompok konseling intensif dibandingkan dengan tidak intensif. Pada kelompok konseling intensif terjadi penurunan kadar CRP dari nilai rerata 8,005 menjadi 5,09 $(p<0,05)$. Hal ini terjadi karena peningkatan pada kualitas diet dan aktivitas fisik menyebabkan perubahan respon metabolik sehingga terjadi peningkatan sitokin anti inflamasi (adiponektin, IL-10) dan penurunan sitokin proinflamasi (TNF- $\alpha$, IL-6, leptin) yang dapat menurunkan stimulasi produksi CRP di hepar. ${ }^{17,31}$

Aktifitas fisik yang kurang dan kualitas diet yang rendah merupakan faktor yang berkontribusi terhadap perkembangan obesitas. Salah satu kriteria dalam penilaian kualitas diet adalah asupan natrium. Asupan tinggi natrium juga dianggap sebagai penyebab tidak langsung dari obesitas karena natrium sering dikaitkan dengan makanan berdensitas energi tinggi dan minuman ringan yang mengandung tinggi gula. ${ }^{18}$ Selain itu asupan tinggi natrium juga berisiko sebesar 1,048 kali terhadap peningkatan kadar CRP. ${ }^{13}$ Pada obesitas terjadi perubahan fungsi adiposit dan makrofag yang menyebabkan hipersekresi adipositokin proinflamasi, proaterogenik, dan prodiabetik. Disfungsi jaringan adiposa juga memproduksi angiotensinogen dan angiotensin II sehinggga berkontribusi terhadap peningkatan tekanan darah. Oleh karena itu, dengan adanya modifikasi gaya hidup terkait peningkatan aktifitas fisik dan kualitas diet dapat memperbaiki profil metabolik meskipun belum terjadi penurunan berat badan. ${ }^{17}$

\section{SIMPULAN}

Konseling modifikasi gaya hidup terkait dengan peningkatan kualitas diet dan aktivitas fisik berpengaruh terhadap penurunan asupan natrium, tekanan darah sistolik, dan kadar CRP. Pada kelompok konseling intensif menunjukkan peningkatan kualitas diet serta penurunan asupan natrium dan kadar CRP yang lebih baik tetapi tidak pada aktifitas fisik. Sedangkan pada kelompok konseling tidak intensif menunjukkan peningkatan aktifitas fisik yang lebih baik tetapi tidak pada peningkatan kualitas diet dan penurunan asupan natrium.

\section{SARAN}

Konseling yang dilakukan secara intensif dapat merubah gaya hidup terkait dengan peningkatan kualitas diet dan aktifitas fisik sehingga terjadi perubahan di tingkat seluler pada sindrom metabolik. Diperlukan penelitian lebih lanjut mengenai pengaruh konseling modifikasi gaya hidup terhadap komponen sindrom metabolik dengan durasi penelitian yang lebih lama. Selain itu juga meneliti variabel lain yang belum diteliti, seperti pengetahuan gizi yang dimiliki oleh orang tua dan praktek penyediaan makanan sehat dalam rumah tangga.

\section{DAFTAR PUSTAKA}

1. Mexitalia M, Agustini Utari, M. Sakundarno, Taro Yamauchi, Hertanto Wahyu Subagio, Agustinus Soematri. Sindroma Metabolik Pada Remaja Obesitas. Media Medika Indosiana. 2009;46(6):3003005.

2. Kubena Karen S. Metabolic Syndrome In Adolescents: Issues and Opportunities. Journal of The American Dietetic Association. 2011.

3. Park Jinkyung, David C. Hilmers, Jason A. Mendoza, Janice E. Stuff, Yan Liu et al. Prevalence of Metabolic Syndrome and Obesity in Adolescents Aged 12-19 Years: Comparison Between The United States and Korea. J Korean Med Sci. 2010;25:75-82.

4. Parlindungan Faisal. Sindroma Metabolik dan Penyakit Kardiovaskular. Fakultas Kedokteran Universitas Sumatra Utara.

5. Sangun Ozlem, Bumin Dundar, Muhammet Kosker, Ozgur Pirgon, Nihal Dundar. Prevalence of Metabolic Syndrome in Obese Children and Adolescents Using Three Different Criteria and Evaluation of Risk Factors. Journal of Clinical Research in Pediatric Endocrinology. 2011;3(2):7076. 
6. Sargowo Djanggan, Sri Andarini. The Relationship Between Food Intake and Adolescent Metabolic Syndrome. Jurnal Kardiologi Indonesia. 2011;32:1423.

7. The IDF (International Diabetes Federation) Consensus Worldwide Definition of The Metabolic Syndrome. The New International Diabetes Federation (IDF) Definition of MetabolicSyndrome [internet]. 2006 [2014 July 10]. Available from: http: www.idf.org/metabolic-syndrome/children/criteria.

8. Urban Lorien E., Susan B. Roberts, Jamie L. Fierstein, Christine E. Gary, Alice H. Lichtenstein. Temporal Trends in Fast-Food Restaurant: Energy, Sodium, Saturated Fat, and Trans Fat Content, United States, 1996-2013. Preventing Chronic Disease, Public Health Research, Practice, and Policy. 2014;11(229):1-7.

9. Organization WHO. World Health Day 2013. A Global Brief on Hypertension, Silent Killer, Global Public Health Crisis. 2013.

10. Amirullah Fattah L. M. Sulchan. Asupan Tinggi Natrium dan Berat Badan Lahir Sebagai Faktor Risiko Kejadian Hipertensi Obesitas Pada Remaja Awal [Thesis Undergraduate]. Nutrition Science: University of Diponegoro. 2012:1-28.

11. Hajer Gideon R., Timon W. van Haeften, Frank L.J. Visseren. Adipose Tissue Dysfunction In Obesity, Diabetes, and Vascular Diseases. European Heart Journal. 2008;29:2959-2971.

12. Halpem Alfredo, Marcio C. Mancini, Maria Eliane C. Magalhaes, Mauro Fisberg, Rosana Radominski, Marcelo C. Bertolami. Metabolic Syndrome, Dyslipidemia, Hypertension, and Type 2 Diabetes In Youth: From Diagnosis To Treatment. Biomed Central: Diabetology and Metabolic Syndrome. 2010;2(55):1-20.

13. Desrini Evi Nurhayati. Asupan Natrium dan Tekanan Darah Sebagai Faktor Risiko Peningkatan Kadar CReactive Protein (CRP) Pada Remaja Dengan Sindrom Metabolik [Thesis Undergraduate]. Nutrition Science: University of Diponegoro. 2014.

14. Brooks C. Gabriel, Michael J. Blaha, Roger S. Blumenthal. Relationship of C-Reactive Protein to Abdominal Adiposity. American Journal Cardiol. 2010;106:56-61.

15. El Shebini Salwa M, Maha I.A. Moaty, Nihad H. Ahmed, Magda S. Mohammed, Yusr M. I Kazem, Salwa T. Tapozada. Association of Nuts and Whole Grains Intake, Inflammation, and The Metabolic Syndrome. Journal of Medicine and Medical Science. 2013;8(1):55-63.

16. Devaraj Sridevi, Uma Singh, Ishwarlal Jialal. Human C-Reactive and The Metabolic Syndrome. 2009;20(3):182-189.

17. Haris Syafrudin, Taralan Tambunan. Hipertensi Pada Sindrom Metabolik. Sari Pediatri. 2009;11(4):257263.

18. Zhu Haidong, Norman K. Pollock, Ishita Kotak, Bernard Gutin, Xiaoling Wang, Jigar Bhagatwala, Sarnip Parikh, Gregory A. Harsfield, Yanbin Dong.
Dietary Sodium, Adiposity, and Inflammation in Healthy Adolescents. Pediatrics. 2014;133(3):635642.

19. Yamaoka Kazue, Toshiro Tango. Effect of Lifestyle Modification on Metabolic Syndrome: a Sistemic Review and Metaanalysis. Biomed Central: Metablism, Diet, and Disease. 2012;10(138):1-10.

20. Tojo Yamaoka Minaka, Taiki Tojo, Kazuki Wakaume, Ryo Kameda, Shinji Nemoto, Naonobo Takahira. Circulating: Interleukin-18: a Spesific Biomarker For Atherosclerosis-Prone Patients With Metabolic Syndrome. Biomed Central: Nutrition and Metabolism. 2011;8(3):1-8.

21. Monzavi Roshanak, Daina Dreimane, Mitchell E. Geffner, Sharon Braun, Barry Conrad, Mary Klier, Francine R. Kaufman. Improvement in Risk For Metabolic Syndrome and Insulin Resistence in Overweight Youth Who Are Treated With Lifestyle Intervention. Pediatrics. 2006;117(6):1111-1118.

22. Physical Activity [internet] [updated January 2015; cited 2015 June 11]. Available from: http://www.who.int/mediacentre/factsheets/fs385/en/

23. Guidelines for Data Processing and Analysis of the International Physical Activity Questionnaire (IPAQ) - Short and Long Forms. 2005;(November):1-15.

24. Notoatmodjo Soekidjo. Pendidikan dan Perilaku Kesehatan. Jakarta: PT Rineka Cipta; 2003.

25. Pujiastuti Endah, Eddy Fadlyana, Herry Garna. Perbandingan Masalah Psikososial Pada Remaja Obes dan Gizi Normal Menggunakan Pediatric Symptom Checklist (PSC)-17. Sari Pediatri. 2013;15(4):201-206.

26. Dienny Fillah Fithra, Martha Irene Kartasurya, Niken Puruhita. Ketidakpuasan Citra Tubuh dan Perilaku Dalam Menurunkan Berat Badan Pada Siswi SMA Di Semarang. Journal of Nutrition and Health. 2014;2(1)

27. Fitri Dyah Kurnia, Rihadini, Maya Dian Rakhmawatie. Perbedaan Stress Antara Remaja Putra dan Putri dengan Obesitas di SMA Negeri 1 Wonosari, Klaten. Jurnal Kedokteran Muhammadiyah. 2012;1(1):54-60.

28. Dewi Ulfah Puspita.Hubungan Antara Densitas Energidan Kualitas Diet Dengan Indeks Massa Tubuh (IMT) Pada Remaja [Thesis Undergraduate]. Nutrition Science: University of Diponegoro. 2013.

29. Hankonen Nelli. Psychosocial Processes of Health Behaviour Change in a Lifestyle Intervention, Influences of Gender, Sosioeconomic Status, and Personality [PhD thesis]. Findland, Qld: University of Helsinki; 2011.

30. Supartha Made, I Ketut Suarta, Ida Bagus Agung Winaya. Hipertensi Pada Anak. Maj Kedokt Indon. 2009;59(5):221-229.

31. Jae Sae Young, Bo Fernhall, Kevin S. Heffernan, Mihye Jeong, Eun Mi Chun, Jidong Sung, Sun Hee Lee, Yun Jeong Lim, Won Hah Park. Effects of Lifestyle Modification of Weight Loss and Improved Aerobic Capacity. Metabolism Clinical and Experimental. 2006;55:825-831 